\title{
Enablers towards establishing and growing South Africa's Waste to Electricity Industry
}

\author{
Heinrich Amsterdam, George Alex Thopil \\ Department of Engineering and Technology Management, University of Pretoria
}

\begin{abstract}
In South Africa the electricity generation mix is relatively un-diverse whereas globally the transformation of the sector is advancing rapidly. Coal remains the predominant fuel source and limited success has to date been achieved in the renewable energy sector. The electricity generation sector is therefore hindered from moving towards an electricity generation landscape where alternative fuel sources is utilised. This research is aimed at gaining insight into the enablers that led towards an increasing trend (observed globally) in exploiting waste as a fuel for electricity generation, and to outline the presence of obstacles that hinder separation of waste for electricity use in the South African context. Furthermore it is an attempt at informing what appropriate interventions (operational and policy) may be considered suitable for South Africa to overcome these barriers in order to enable a sustainable South African waste to electricity (WTE) Industry. Findings show that numerous barriers to a WTE exists in the South African context, however overcoming these barriers is not as simple as adopting the European model with the aim to modify the electricity generation mix and waste management landscape. Selected enablers deemed appropriate in the South African context are adapted from the European model, and are greatly influenced by the prevailing socio-economic status of South Africa. Primary enablers identified were, (i) government support is needed especially in the form of subsidisation for green energy, (ii) increase landfill costs through the implementation of a landfill tax, (iii) streamline the process for Independent Private Power Producers (IPPPs) to connect to the national grid with off-take guaranteed and the inclusion of WTE into an electricity roadmap (effectively government's strategy). The proposed enabling interventions would help in overcoming the barriers for a South African WTE industry.
\end{abstract}

Keywords: electricity, enablers, barriers, waste to energy, South Africa

\section{Introduction}

Globally the demand for energy and in particular for electricity is intensifying. Electricity plays a vital role in individual and collective daily activities, and is easily the most mobile source of energy consumed on a daily basis. Overall it enables humans to lead an enhanced quality of life (Armaroli and Balzani, 2011) and is referred to as the driver of economic growth (Keho, 2016). Ramírez-Camperos et al., (2013), states that electricity is a fundamental input into society's well-being and a country's corresponding economic development. Therefore a lack of generating capacity is likely to have a negative effect on a country's economic outlook (Balachandra, 2006); (Keho, 2016). Overall the world experienced a significant increase in demand for electricity during the $21^{\text {st }}$ century, stimulated by a growing world population, industrialisation, urbanization, income growth and modernisation (Pazheri et al., 2014), (Keho, 2016). According to the EIA 2016 energy outlook report, energy demands are expected to increase from 524 quadrillion Btu (2010 levels) to almost 820 quadrillion Btu by 2040 (EIA, 2016). On the other hand Pavlović et al., (2012) predicts that in the next 15 to 20 years the consumption of electricity will double. The bulk of this increase is expected to be stimulated by developing countries (Balat, 2006).

At present the primary fuel source used for electricity generation is coal (Aslani et al., 2012). Jamel et al., (2013) and Balat (2006) states that the bulk of global electricity generation capability is built on fossil fuels $(66 \%$ of electricity generated utilising coal as a fuel) however South Africa in particular even more dependent on coal compared to the 
overall trend observed globally. Pazheri et al., (2014) reveals that more than $90 \%$ of the electricity generated in South Africa is based on coal. Thopil and Pouris, (2015) states that 95\% of South Africa's electricity generation capacity is based on non-renewable energy with the delta made up by nuclear energy sources. On numerous occasions Eskom failed to satisfy the demand for electricity in South Africa which led to load shedding in order to keep the grid stable and to avoid a total blackout.

The aim of this research is to identify/investigate the enablers that led towards an increasing trend (observed globally) in exploiting waste as a fuel for electricity generation (hence the establishment of a WTE industry/sector), and then to identify what local barriers exists in the South African context. Based on a thorough understanding of these identified local barriers, enablers which can lead to establishing a sustainable WTE industry specific to the South African context are proposed and tested. The overall objective is therefore to reveal the absence of a waste to electricity (WTE) industry in South Africa, what obstacles is preventing this industry from being embedded into the local electricity generation mix and finally what enablers (operational and policy interventions) should be considered to give effect to a sustainable WTE industry. This research is relevant particularly for developing countries where waste disposal is still skewed towards land filling and where electricity generation is still dominated by fossil fuels. The process followed in this research can be used in identifying the local factors (or barriers) that need to be considered for the development of a local WTE industry.

Diversifying South Africa's electricity generation mix by including waste as a resource carries a number of benefits. It conserves natural resources and in the process reduces the volume of waste that is landfilled and thereby contributes to environmental protection (Menikpura et al., 2016), (Brunner and Rechberger, 2015), (Ruth, 1998). Waste quantities is increasing and the corresponding amounts must be treated (Münster and Meibom, 2011). Pavlas et al., (2010) states that the landfill option's capability to manage waste which has not been pre-treated in order to reduce its organic content is limited, and thus requires more effective methods of waste processing. This reality leaves municipalities with an ever increasing concern about this matter. WTE is now being considered as an option to tackle the growing waste management challenges in developing countries (Menikpura et al., 2016), (Bidart et al., 2013), (Ouda et al., 2013), (Ofori-Boateng et al., 2013), (Guerrero et al., 2013), (Melikoglu, 2013). Further Saidur et al., (2011) claims that WTE can simplify disposal and can potentially be an inexpensive source of heat.

It further holds the benefit that WTE can conserve valuable energy resources and protect the environment by conserving energy and natural resources (Ruth, 1998), (Menikpura et al., 2016). Psomopoulos et al., (2009) states that according to actual operating data collected in the United States, that on average combusting 1 ton of MSW in a modern WTE plant, results in the generation of approximately $600 \mathrm{KWh}$ of electricity and further avoid the mining of 0.25 tons of coal or the importing of a barrel of oil. In addition Hartenstein and Horvay, (1996) as well as Psomopoulos et al., (2009) claims that WTE is the only way of sustainably disposing non-recyclable municipal waste.

The paper starts of by proposing an initial model for the local WTE industry drawn from European cases, in particular Sweden (Williams, 2011). Gaps in the model are then tested through two rounds of expert views. Throughout it is clear that the socio economic reality in South Africa is strongly influencing the emerging views. These emerging views and data collected (determining relevance of barriers to test for convergence) then necessitated a variation to the initial model that takes the South African socio-economic constraints into consideration. The revisited model and formulation process can be applied for other countries with similar waste disposal challenges and socio economic conditions. 


\section{Background}

The generation of municipal solid waste (MSW) driven by rapid urbanisation is an unavoidable consequence due to human activity and is the most prevalent by-product (Lino and Ismail, 2011), (Teixeira et al., 2014), (Brunner and Rechberger, 2015). Urbanisation is predicted to continue and by 2025 the world population is projected to reach the 8 billion mark with 5 billion residing in urban areas (Menikpura et al., 2016). The World Bank estimates that the number of urbanised inhabitants will reach 4.3 billion by 2025 , of which each person will generate approximately $1.42 \mathrm{~kg} / \mathrm{capita} / \mathrm{day}$ of municipal solid waste that totals to 2.2 billion tons/year globally (Hoornweg and Bhada-Tata, 2012). This represents a sharp increase from the current estimates of 1.3 billion tons/year. Consequently this growth brings about many challenges as far as the management of MSW is concerned (Assamoi and Lawryshyn, 2012). The conventional means globally to manage MSW is predominantly landfilling, composting, recycling and WTE (Psomopoulos et al., 2009). In the National waste information baseline report (Department of Environmental Affairs, 2012), South Africa's waste volumes were modelled/estimated drawing from the 2011 census data and previous work done in 2005 determining the mass and per capita waste generation per province. Department of Environmental Affairs (2012) concludes that South Africans generate in total 108 million tons per annum of waste. General waste makes up 59 million of this total, hazardous waste 1 million and the remainder is unclassified. Of the general waste $10 \%$ is recycled, equating to 53.1 million tons assumed to be landfilled. This report also indicated that MSW quantities is growing faster in some cities than the country's economy.

Waste disposed to land presents a number of environmental challenges such as emissions of gases, water and land pollution, noise, vermin, dust and odour (Teixeira et al., 2014), (De Feo et al., 2013). Waste to energy provides for a suitable waste management solution, and in addition addresses energy supply concerns within a region (Monni, 2012), (Miranda and Hale, 1997). The European Union (EU) now classifies energy efficient waste incinerators as waste recovery units and therefore the activity moved up on the waste hierarchy (Münster and Meibom, 2011). This certainly plays a critical role when engagement with stakeholders is required, especially during authorisation applications for the erection of such facilities. Waste incineration reduces $\mathrm{CO}_{2}$ emissions achieved through the removal of organic components from landfills (thus avoiding anaerobic degradation) which under certain conditions would have generated biogas that would normally be emitted into the ambient air even in the presence of landfill gas capturing systems (Menikpura et al., 2016), (Zheng et al., 2014). Ang and Su, (2016) puts forward that electricity generation sector's potential to reduce greenhouse gas (GHG) emissions is great by switching to non-fossil fuels especially away from coal. In a review undertaken by Psomopoulos et al., (2009) on WTE plants in the United States it was found that emissions of acids, dioxins/furans, mercury as well as greenhouse gases (GHG) is significantly lower than what is detected from conventional coal fired power plants. In addition the emissions are significantly lower when compared to the European Union and United States Environmental Protection Agency standards for all pollutants. Monni (2012) found that emissions from WTE plants dedicated to electricity generation was $35-60 \%$ lower when compared to electricity production within the same district from fossil fuel fired power plants when taking avoidance of emission from landfills into account. It is therefore verifiable that WTE provides cleaner and reliable energy compared to conventional fuels (Habib et al., 2013), (Pavlas et al., 2010). Lastly WTE plants has a negligible impact on land use (and land cost) partly because if properly maintained it can last well over 30 years (Psomopoulos et al., 2009) and it will not require more land than initially earmarked unless a WTE facility is expanded to handle more waste.

A causal relationship exists between electricity consumption and economic growth (expressed as Growth Domestic Product). In the Association of South East Asian Nations 
(ASEAN), Yoo (2006) found that there is a bi-directional relationship between electricity consumption and economic growth for Malaysia and Singapore. It implies that electricity consumption and economic growth is interrelated whereby the one impacts on the other. These findings corroborate the important role electricity plays in the competitiveness of a country. In a number of countries the results is much clearer for example in Turkey stronger evidence suggests a unidirectional causality running from electricity consumption to economic growth (Altinay and Karagol, 2005). The authors concludes that a sustainable electricity supply is crucial for the growing demand and subsequent economic growth for Turkey. Fatai et al., (2004) concluded that the conservation of energy resources may have a greater impact on Asian countries when compared to more industrialised and developed countries. Based on this it can be concluded that a shortfall in electricity generation is likely to have a material effect on developing countries and therefore also on the South African economy. For South Africa, Odhiambo (2010) shows a bi-directional causality between electricity consumption and economic growth. It implies that policy directed at expanding electricity infrastructure to support the growing demand for the utility is essential for South Africa. Eskom, South Africa's power utility has been unable to satisfy the demand from its market for a number of years now. Krupa and Burch (2011) stated that a convergence of mass electrification, strong economic growth and inadequate maximum load planning resulted in the demand for power to surpass the generating capacity in South Africa. In 2008 the shortfall was estimated at 10\% (Sebitosi and Pillay, 2008). Pegels (2010) estimated the cost to the South African economy due to the 2008 load shedding event between 253-282 million USD and the National Energy Regulator of South Africa (NERSA) estimated it to be in the order of 50 billion Rands (Inglesi, 2010).

It is imperative that the gap between the demand and supply of electricity is breached in a sustainable, economically feasible and socially acceptable manner. Several initiatives to supplement the available generation capacity in order to address the said shortfall has already been committed, such as the construction of additional generation capacity (Medupi- and Kusile coal fired power station), improved maintenance on the current system and awareness to the general population on electricity conservation (or improved efficiency). Further a Renewable Energy Independent Power Producer Procurement Programme (REI4P) was launched to further address the electricity shortage. The REI4P is tasked to install 3,725 MW of renewable energy by 2016. Positive strides have been made in this regard, however up to now the programme is yet to fulfil its promise. In a review, McDaid (2014) reports that the REI4P further committed an additional $3200 \mathrm{MW}$ (total generating capacity of $6,725 \mathrm{MW}$ ), however to date only 3,916 MW has been awarded to private producers. Construction on the Medupi and Kusile coal fired power stations is well underway and the REI4P has yielded positive results, but has not yet produced the intended $6,725 \mathrm{MW}$ generation capacity to declare the initiative a success. Alternative mechanisms/avenues to fulfil the renewable energy targets can also be considered to reach the intended target set for the South African market to support the economy. One such avenue that remains reasonably underdeveloped is Waste to Energy (WTE) which may offer a valuable contribution towards breaching the electricity generation shortfall experienced by South Africa's power utility. This fuel source (waste) is readily available, and beneficial utilisation may potentially benefit the country's economy. A review of the literature did not reveal the existence of a formal WTE industry in South Africa, nor are there policies to support/enable such an industry as is the case with renewable (solar and wind) energy. It gives the impression that barriers obstructing the exploitation of waste as a fuel source for electricity generation exist.

South Africa should explore WTE as a viable source of energy particularly for electricity generation. It has merit as a waste management option owing to its use by other countries such as the United States, the European Union (majority of member states) as well as in a number of Asian countries. WTE is predominantly undertaken to address the growing 
waste management challenges in developing countries (Menikpura et al., 2016). Saidur et al., (2011) claims that WTE can simplify waste disposal and can potentially be an inexpensive source of heat. Therefore alternatives to landfilling of waste exist and WTE is a suitable enabler and alternative given its electricity generation capability. Hoornweg and Bhada-Tata (2012) point out that WTE is the $3^{\text {rd }}$ biggest disposal option to manage MSW. Further Massarutto (2015) states that on average 19\% of MSW are incinerated within OECD countries and almost all forms of incineration are incorporated with energy recovery systems. Overall the WTE industry is more mature in Europe than in the rest of the world with +300 operational WTE facilities and reportedly a total of 2150 incineration plants existing globally (Baxter et al., 2016). Psomopoulos et al., (2009) indicates that in the United States (US) 88 WTE plants combust 26.3 million tons of MSW and that it serve 30 million people. Further WTE accounts for the disposal of more than $7 \%$ of the total waste generated in the United States. It corresponds to an electricity generation capacity net of $13.5 \times 10^{9} \mathrm{KWh}$ of electricity which is greater than all renewable energy sources with the exception of hydroelectric and geothermal power.

The WTE industry in Sweden experienced exceptional growth from 10\% in 1980s to $22 \%$ by 2009. In addition the country achieved a significant decline in coal consumption from peaking at over 5 trillion tons of coal consumed in 1986, to approximately a third of that at 1.8 trillion tons with a corresponding increase in incineration with energy recovery systems from 1999 to 2010 (Williams, 2011). Williams (2011) undertook a study where investigating the WTE industry in Sweden revealed the following important factors drawn from the Swedish WTE industry model for application/transfer into the US.

- High landfill fees even with abundant land available. Comparatively landfill tipping fees per ton on average where \$175 compared to \$44 dollars in The United Sates. The author further concludes that in the US most WTE plants are in operation in areas where the tipping fees is the highest.

- Placing a price on carbon emissions to incentivise emitters to reduce its emissions. Sweden's price on carbon tax fluctuates significantly from fossil fuel to waste, with the former significantly higher. It therefore resulted in the conversion to biomass/waste as a fuel since burning fossil fuel is much more expensive in Sweden.

- High landfill taxes that assist in recycling and WTE and no tax for burning MSW for energy exists. It was noted that in the United States there is currently no landfill tax.

- Recognition of WTE as a renewable energy. In Europe (and Sweden) the organic portion of waste is considered renewable, qualifying WTE for incentives which it otherwise would not have been eligible for.

- Adequate supply of waste (feedstock).

- Public support. The citizens are more supportive of recycling; however they are generally supportive of WTE plants.

It is estimated that Eskom (a state owned company) generates about two thirds of the total sub-Saharan electricity output and $80 \%$ of the Southern African output (Odhiambo, 2009) and that more than half of the electricity produced in Africa comes from South Africa, thus Eskom (Odhiambo, 2010). The energy mix in South Africa is predominantly coal (86\% of total energy mix) based (Pegels, 2010). Eskom (2015) reported for the period 01 April 2014 to 31 March 2015 that it operated 23 power stations and that the energy mix for the period added up to a total nominal capacity of $42,090 \mathrm{MW}$. It comprised of $35,721 \mathrm{MW}$ generated through coal fired power stations, $1,860 \mathrm{MW}$ of nuclear power, $2,409 \mathrm{MW}$ of gas-fired, $600 \mathrm{MW}$ hydro and $1400 \mathrm{MW}$ pumped storage stations, as well as a recently commissioned $100 \mathrm{MW}$ Sere Wind Farm. This equates to $\sim 85 \%$ of coal within the 
energy mix. Not much has changed compared to what was reported about the energy mix in 2010 (Pegels, 2010).

Coal is a relative cheap fuel source especially given that South Africa has the $6^{\text {th }}$ largest coal reserve in the world. In addition coal is easily accessible (Pegels, 2010), (Thopil and Pouris, 2015). This has led to average price of $0.75 \mathrm{R} / \mathrm{kWh}\left(0.06 \mathrm{USD} / \mathrm{kWh}^{1}\right)$ for coal based bulk electricity being significantly cheaper (in spite of significant increases over the past 8 years) as compared to the indicated price of $0.94 \mathrm{R} / \mathrm{kWh}(0.07 \mathrm{USD} / \mathrm{kWh})$ for electricity from landfill gas during the third bidding window of REI4P derived from waste (Green Cape, 2015). These numbers are seen as a likely barrier that hinders the establishment of a formal WTE industry in South Africa. Furthermore, South Africa's low landfill tipping fees, which range from $\mathrm{R}$ 100-150/tonne (USD 7.7-11.5/tonne) for general waste (Linda Godfrey et al., 2013) with the highest tipping fee for certain municipalities being reported to be $\mathrm{R}$ 450/tonne (USD 34.6/tonne) (Green Cape, 2015), in combination with the absence of landfill taxes may contribute to a weak WTE industry/sector. These fees are in contrast to an average waste disposal fee (landfill taxes included) of 80-100 Euro/tonne in Europe, with Sweden having a disposal fee as high as 150 Euro/tonne (EEA, 2014). This scenario has even led to waste from Europe being transported to be landfilled in South Africa (Infrastructure News, 2016).

Given the legacy problems linked to landfilling in South Africa, waste diversion from landfill should be an important agenda item to address quality of life as well as the associated economic benefit by increasing electricity generation capacity. Although the waste quantities in South Africa is following global trends it is however not following the advanced and innovative waste management solutions seen in European countries and to a lesser extend the USA. South Africa has very little installed WTE capacity and thus demonstrates that such an industry does not exist. Based on the literature review of enablers that led towards an increasing trend (observed globally) in exploiting waste as a fuel for electricity generation, the following part of the paper frames a conceptual model required to develop a WTE in South Africa. Local enablers required to the overcome the identified barriers are then proposed and tested, after which a revised model for the South African WTE industry is developed.

\section{Methodology}

In order to advance and establish a South African WTE industry a conceptual model (figure 1) was proposed. The initial literature review and in particular the interventions in Europe to drive WTE towards the established industry it turned out to be today, informed the proposed conceptual model. Initially it was intended for application to the South African context without altering the model; however the data analysis revealed a framework that takes the local socio-economic constraints into consideration should be adopted. This conceptual model formed the basis to examine linkages between a nonexistent WTE industry in South Africa that currently demonstrates a reluctance to grow, and a number of possible barriers/obstacles that should be bridged.

\footnotetext{
${ }^{1} 1$ USD = 13 ZAR (June 2017 exchange rates) Note: Exchange rates have to be treated with caution due to volatile nature of the South African Rand)
} 


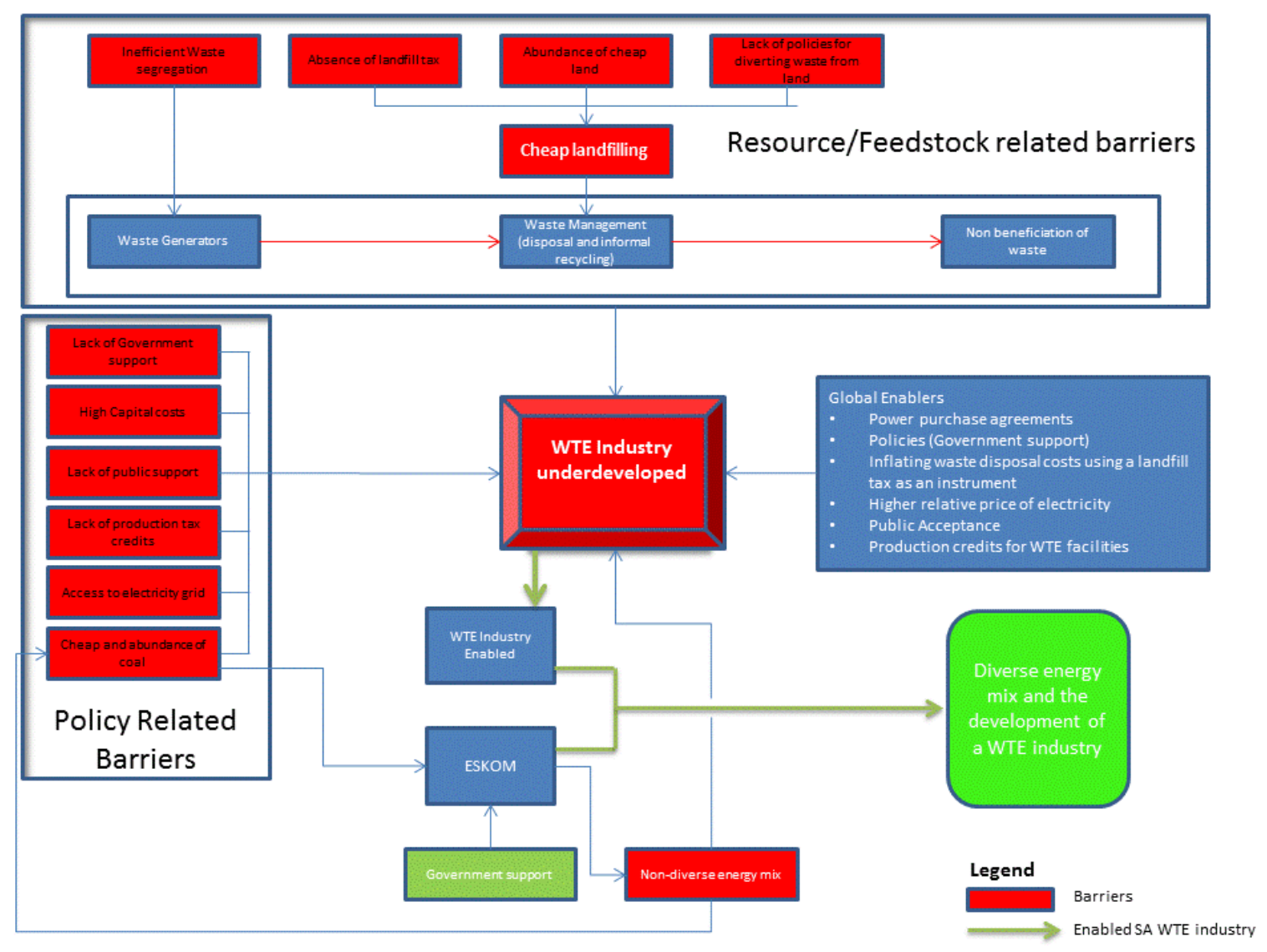

Figure 1: Conceptual model to develop a WTE industry in South Africa

The proposed model suggests that in general there is very little initiative to implement effective waste segregation or to change behavioural patterns. This is mainly due to the abundance of land and the absence of policies to influence the behaviour of the population. The reason for this situation is because landfilling in South Africa is relatively cheap and is therefore an affordable means to handle and dispose waste. This situation has been relatively the same over the past decade and has shown hardly any signs of improvement (Trois and Simelane, 2010), (Nahman, 2011), (Nahman and Godfrey, 2010), (Matete and Trois, 2008), (Godfrey, 2008). The consequence is that WTE is assumed to experience a resource/feedstock constraint, which is a vital input to ensure the sustainability of WTE. On the other hand policy related constraints are believed to exist. The model highlights that the lack of government support, high capital costs of WTE, lack of public support and subsidies, limited access to the grid and cheap coal collectively contributes to restrain WTE from being established. This conceptual model suggest that both Eskom and a WTE industry should work together to diversify South Africa's energy mix. Several interventions are however necessary to realise an environment wherein both entities can contribute meaningfully towards a diversified energy mix. A number of research propositions/enablers based on the preliminary examination of the literature was therefore put forward and will be carefully tested as part of this research.

\section{Research propositions}

- The South African policy makers must implement reasonable tax and production credits to stimulate its WTE industry.

- The implementation of a carbon tax policy that is aimed to divert waste away from landfill will stimulate the South African WTE industry. 
- The introduction and effective administration of landfill taxes will stimulate a South African WTE industry.

- South Africa should introduce policies that define the organic portion of waste as renewable energy in order to stimulate the South African WTE industry.

- A gradual or significant increase in disposal cost in South Africa will stimulate the South African WTE industry

- Increasing the cost of electricity will stimulate the South African WTE industry

- Influencing public perception by means of awareness and the corresponding visible enforcement of air pollution will stimulate the South African WTE industry

\section{Research approach}

This research followed a qualitative exploratory research design to investigate linkages between the proposed barriers and a non-existent WTE industry in South Africa and to propose enablers to overcome the identified constraints.

Qualitative $\left(1^{\text {st }}\right.$ round Delphi method/technique) - Semistructured interviews with key role players in the field of waste management to:

- Explore which barriers (if any) contributes to a nonexistent WTE industry
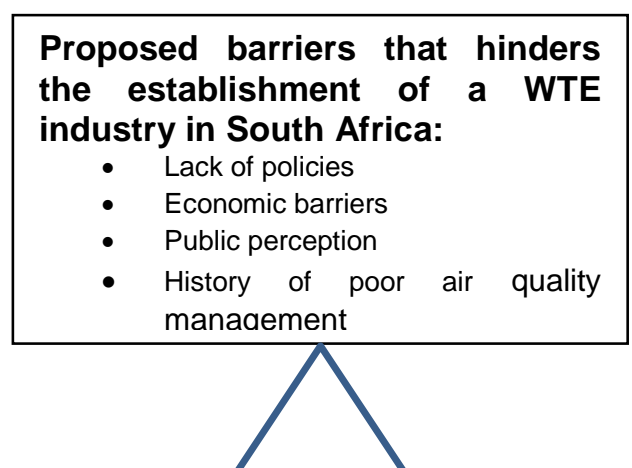
open ended questioning with some control exercised by the researcher to navigate the process.

Table 1: List of industry experts interviewed

\begin{tabular}{|c|c|c|}
\hline $\begin{array}{l}\text { Interviewee reference } \\
\text { in report }\end{array}$ & Role in Industry & $\begin{array}{l}\text { Interviewed during } 2^{\text {nd }} \\
\text { round interviewing }\end{array}$ \\
\hline Interviewee 1 & $\begin{array}{l}\text { Senior Research Manager: } \\
\text { Alternative Waste management }\end{array}$ & Yes \\
\hline Interviewee 2 & $\begin{array}{l}\text { Divisional Director: Major Waste } \\
\text { Management company }\end{array}$ & Yes \\
\hline Interviewee 3 & Commercial Waste Specialist & No \\
\hline Interviewee 4 & $\begin{array}{l}\text { Director: Environmental Affairs } \\
\text { (Waste division) }\end{array}$ & No \\
\hline Interviewee 5 & $\begin{array}{l}\text { Technical Director: Major Waste } \\
\text { Management company }\end{array}$ & Yes \\
\hline Interviewee 6 & $\begin{array}{l}\text { Environmental Engineer-Waste } \\
\text { Beneficiation }\end{array}$ & No \\
\hline Interviewee 7 & $\begin{array}{ll}\text { Environmental } & \text { consultant } \\
\text { (associate partner) } & \end{array}$ & Yes \\
\hline Interviewee 8 & Director of waste recovery entity & Yes \\
\hline Interviewee 9 & Environmental Specialist & No \\
\hline Interviewee 10 & Environmental Scientist & Yes \\
\hline Interviewee 11 & $\begin{array}{l}\text { Manager: Waste } \text { Research, } \\
\text { Development and Innovation } \\
\text { Roadmap Implementation }\end{array}$ & No \\
\hline
\end{tabular}

The data collected was analysed by means of a Computer Assisted Coding (CAC) program called Atlas.ti ("Atlas.ti," 2016). It works on the basis of coding statements (referred to as quotations) made by respondents in relation to a subject matter. Codes was created keeping in mind the research objectives and research propositions. The amount of quotations embedded in a code was at this very early stage of the data analysis process used to filter data. It assisted with the identification of commonalities, distinct differences and emerging patterns. It gave rise to emerging themes common to all interviews. Atlas.ti has been used to analyse governance and legislation in the nuclear industry (Heffron, 2013), (Ruuska et al., 2011), assess innovation in the power sector (Rogge et al., 2011) and to identify barriers in the renewable energy sector (Ahlborg and Hammar, 2014).

The second round of analysis was based via a $2^{\text {nd }}$ round of interviews with a selected number of interviewees from round 1 . The aim of round 2 was to rank and rate barriers (identified during round 1 ) with the aim of establishing convergence. Table 1 (column 3) highlights which experts were interviewed during this round of interviews.

Data analysis was conducted in accordance to the method (figure 3) outlined below:

- Manual coding of primary data sources

- Identification of broad/emerging themes 
- $\quad$ CAC of the primary data resulting in a quotation database

- Analysis of CAC results by looking at code co-occurrence as well as frequencies within the data

- Compare coded data with initial and rival propositions

- Triangulation of data (outcome of theory developed through the above steps) through a $2^{\text {nd }}$ round of interviews. This was to construct internal validity

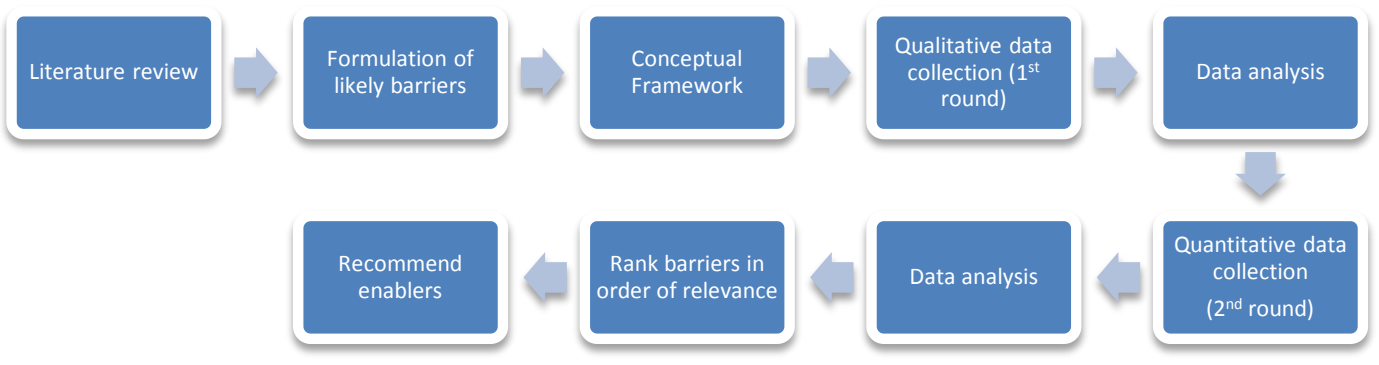

Figure 3: Research Methodology

\section{Results}

For the $1^{\text {st }}$ round a total of 15 respondents were invited to participate in this research and 11 responded positively to this request. The data analysis tools available as part of the Atlas.ti qualitative data analysis software ("Atlas.ti," 2016) that was utilised are, coding (code count and complementary groundedness) and code co-occurrence. In addition these tools assist with structuring and filtering of the primary data. The initial coding (primary data analysis) process highlighted 4 dominant emerging themes. A secondary coding step followed and revealed emerging patterns as well as dominant views within individual themes. The results/analysis of the 4 emerging themes and identified emerging views is listed in Table 2 below.

\subsection{First round analysis}

Table 2: Emerging themes and emerging views

\begin{tabular}{|l|l|}
\hline $\begin{array}{l}\text { Emerging themes } \\
\text { (ET) }\end{array}$ & Emerging views (EV) \\
\hline $\begin{array}{l}\text { Theme 1: Explaining } \\
\text { the difference } \\
\text { between Europe and } \\
\text { South Africa }\end{array}$ & $\begin{array}{l}\text { Emergent view 1a: European countries have a more mature and } \\
\text { healthy economy where the public are generally supportive of } \\
\text { alternative sources of energy }\end{array}$ \\
\cline { 2 - 2 } & $\begin{array}{l}\text { Emergent view 1b: Europe is constrained for land and needed to } \\
\text { advance into alternative waste management opportunities }\end{array}$ \\
\cline { 2 - 2 } & $\begin{array}{l}\text { Emergent view 1c: Europe experienced a legislative push } \\
\text { towards WTE by promulgating key policy documents }\end{array}$ \\
\hline $\begin{array}{l}\text { Theme 2: Explaining } \\
\text { why South Africa's } \\
\text { energy mix remains } \\
\text { un-diverse }\end{array}$ & $\begin{array}{l}\text { Emergent view 2a: Eskom is hindering Independent Private } \\
\text { Power Producers (IPPP) access to the national electricity grid }\end{array}$ \\
\cline { 2 - 2 } & $\begin{array}{l}\text { Emergent view 2b: A power purchase agreement application is a } \\
\text { long protracted process and not easy to come by }\end{array}$ \\
\cline { 2 - 2 } & $\begin{array}{l}\text { Emergent view 2c: Coal is cheap and in abundance in South } \\
\text { Africa and allows the country to produce cheap electricity } \\
\text { otherwise not possible through alternatives. }\end{array}$ \\
\hline Theme 3: Reasons & $\begin{array}{l}\text { Emergent view 3a: A secure supply of feedstock cannot be } \\
\text { guaranteed }\end{array}$ \\
\hline
\end{tabular}




\begin{tabular}{|c|c|}
\hline \multirow{6}{*}{$\begin{array}{l}\text { environment a WTE } \\
\text { industry is not } \\
\text { feasible/established } \\
\text { in South Africa }\end{array}$} & $\begin{array}{l}\text { Emergent view } 3 \mathbf{b} \text { : South Africa is lacking a culture of waste } \\
\text { segregation and recycling }\end{array}$ \\
\hline & $\begin{array}{l}\text { Emergent view 3c: WTE is a capital intensive solution and } \\
\text { negatively affects its financial feasibility }\end{array}$ \\
\hline & $\begin{array}{l}\text { Emergent view 3d: The present cost to landfill waste weakens } \\
\text { the financial feasibility of a WTE industry/facility }\end{array}$ \\
\hline & $\begin{array}{l}\text { Emergent view 3e: Coal is cheap, available in abundance and } \\
\text { therefore WTE cannot compete financially with coal fired power } \\
\text { stations }\end{array}$ \\
\hline & $\begin{array}{l}\text { Emergent view 3f: The price of electricity in South Africa is not } \\
\text { supportive of a WTE industry }\end{array}$ \\
\hline & $\begin{array}{l}\text { Emergent view } \mathbf{3 g} \text { : There is a lack of government support and } \\
\text { incentive for green energy }\end{array}$ \\
\hline \multirow{6}{*}{$\begin{array}{l}\text { Theme 4: Proposals } \\
\text { to enable a } \\
\text { Sustainable South } \\
\text { African WTE } \\
\text { Industry }\end{array}$} & Emergent view 4a: Raising the cost of landfilling is not advised \\
\hline & $\begin{array}{l}\text { Emergent view 4b: Hiking the electricity price is unacceptable } \\
\text { given the socio-economic status and economy of South Africa }\end{array}$ \\
\hline & $\begin{array}{l}\text { Emergent view 4c: Several financial instruments (carbon-, landfill } \\
\text { tax and production levies) can be used as a lever to bridge the } \\
\text { barriers to a WTE industry, but caution must be taken }\end{array}$ \\
\hline & $\begin{array}{l}\text { Emergent view 4d: Technically waste cannot be classified as } \\
\text { renewable energy source }\end{array}$ \\
\hline & $\begin{array}{l}\text { Emergent view 4e: Allow IPPs access to the national electricity } \\
\text { grid and simplify the application process }\end{array}$ \\
\hline & $\begin{array}{l}\text { Emergent view 4f: In South Africa a WTE industry must be } \\
\text { subsidised (with applicable levies) to kick start investor interest. }\end{array}$ \\
\hline
\end{tabular}

Theme 1: Explaining the difference between Europe and South Africa

Emergent view 1a: European countries have a more mature and healthy economy where the public are generally supportive of alternative sources of energy

Emergent view 1b: Europe is constrained for land and needed to advance into alternative waste management opportunities

Emergent view 1c: Europe experienced a legislative push towards WTE by promulgating key policy documents

The above analysis suggests that the general South African public is not necessarily aware of the benefits associated with WTE and the wide-ranging alternatives (including WTE) available to beneficially handle waste. The population has different priorities primarily to provide for its basic needs in the form of shelter, food, water and clothing. Enabling a WTE industry through efficient waste segregation and recycling is therefore not a priority. There is overwhelming consensus amongst interviewees that the lack of available and cheap land steered the European strategy towards WTE as an alternative for waste management. Seemingly the necessity to limit the distances waste is hauled played a pivotal role in the move towards WTE as a solution to the land challenge in Europe. Unavailability of land further resulted in financial support from governments to keep these facilities in operation. Contrary to this South Africa does not have a problem with land although the challenge (in the major metropolitan cities) for continued disposal in close proximity to economic activity is increasingly faced by municipalities. Legislation binding member states in the EU called for radical changes in the approach to both the management of waste as well as the combined makeup of its energy mix which pushed WTE. 
Theme 2: Explaining why South Africa's energy mix remains non-diversified

Emergent view 2a: Eskom is hindering Independent Private Power Producers (IPPP) access to the national electricity grid

Emergent view 2b: A power purchase agreement (PPA) application is a long protracted process and not easy to come by

Emergent view 2c: Coal is cheap and in abundance in South Africa and allows the country to produce cheap electricity otherwise not possible through alternatives.

The storage of electricity in huge quantities is not technically feasible and therefore the overall generation must equal distribution capacity and demand from consumers. Eskom through its coal fired electricity generation capability provides for the base load into the national grid and sacrificing some of the electricity supply to accommodate private producers implies cutting back on its own production volumes. For the sake of stability in the grid additional generating capacity may be required during peak loads which Eskom may be willing to offer to IPPPs since it is often forced to commission less cost effective auxiliary plants fuelled by diesel and gas to satisfy the peak demand. Private investors would expect their investment (a WTE facility) to operate all day long in order to be considered economically feasible. It implies an IPPP's wish to contribute towards the base load and not only just during peak load periods. This may perhaps be a recipe that contributes to an IPPP's avoidance of entering into this market and therefore WTE is not able to attract much needed investment to stimulate it. In addition the overall sentiment based on responses was that gaining access to the grid is an onerous process and that the government must intervene to streamline the process to better accommodate private producers who wish to gain access to feed electricity into the national electricity grid. PPAs are extremely difficult to obtain and government should revise its strategy for electricity generation and develop an electricity generation roadmap to provide for a charter to pursue the diversification of the country's energy mix. Further, ideally all stakeholders (government, industry and the public) should collaborate and jointly develop a strategy that intends to serve the needs of the country. The current state of affairs gives the impression that the willingness to create a forum to enable such discussions appears to the absent within a South African context. Currently in excess of $90 \%$ of electricity generation capacity in South Africa is based on coal as a fuel. Cheap and readily available coal is being put forward as a hindrance to the diversification of South Africa's energy mix. Furthermore, South Africa cannot reach the same efficiencies for WTE facilities. On the other hand and efficient WTE facility contributed significantly to a booming European market due to it's feed-in towards district heating. Finally the responses hinted at South Africa's economic sustainability that relies heavily on the availability of cheap coal to produce cheap electricity to realise acceptable economic growth in the short to medium term.

Theme 3: Reasons why in the current environment a WTE industry is not feasible/established in South Africa

Emergent view 3a: A secure supply of feedstock cannot be guaranteed

Emergent view 3b: South Africa is lacking a culture of waste segregation and recycling

Emergent view 3c: WTE is a capital intensive solution and negatively affects its financial feasibility

Emergent view 3d: The present cost to landfill waste weakens the financial feasibility of a WTE industry/facility

Emergent view 3e: Coal is cheap, available in abundance and therefore WTE cannot compete financially with coal fired power stations

Emergent view 3f: The price of electricity in South Africa is not supportive of a WTE 
industry

Emergent view 3g: There is a lack of government support and incentive for green energy

A secure feedstock for WTE facilities is an important aspect that contributes to its long term sustainability and must be addressed to attract investors towards this market. Adding value to waste threatens the sustainability of a WTE industry and the likely competition for waste has the potential to drive the value creation of waste. Respondents argued that an adequate quantity of waste is being generated in South Africa. Generally there is consensus that informal and suboptimal waste segregation and recycling practices prevails in South Africa, however a spilt appears on opinions put forward on who the benefactor(s) of the segregated waste streams should be. Some argue that waste volumes should be evenly distributed to all concerned parties, whereas the opposite arguments supports the waste hierarchy which implies that the recycling industry (formal or informal) should be preferred. Some respondents argued that a failing recycling industry favours a WTE industry however in most cases (dependant on the technology used) a homogenous waste stream is required and better waste segregation and recycling improves the chances of this happening. WTE is an expensive technology and the economics does not compare favourably with landfilling of waste, especially since it is argued that both technologies competes on the same footing as far as environmental protection is concerned. The capital intensity therefore impacts negatively on a WTE industry. The present cost to landfill weakens the financial feasibility for a WTE facility/industry. The true cost incurred to landfill is not yet fully understood. Further coal is cheap resulting in a low electricity price that severely impacts on the feasibility of a WTE industry. The quotes extracted from transcripts suggest that the electricity price appears to be a barrier and that a hike in electricity price will result in a more favourable business case for WTE. Commenting on the hiking of electricity prices to support a WTE industry was however extensive and is further dealt with within theme 4 where this study explores interventions aimed at enabling a WTE industry. This section highlights the importance of government support to enable a WTE industry in South Africa. It suggests that government holds the key in light of its privileged position held in society, being able to implement policies to support WTE. It can also exercise its authority over Eskom should a decision be made that the electricity generation agenda includes WTE. The general consensus is however that there is a lack of appetite from government for WTE although waste diversion has been identified as a key strategic objective.

Theme 4: Proposals to enable a Sustainable South African WTE industry

Emergent view 4a: Raising the cost of landfilling is not advised

Emergent view 4b: Hiking the electricity price is unacceptable given the socio-economic status and economy of South Africa

Emergent view 4c: Several financial instruments (carbon-, landfill tax and production levies) can be used as a lever to bridge the barriers to a WTE industry, but caution must be taken

Emergent view 4d: Technically waste cannot be classified as renewable energy source

Emergent view 4e: Allow IPPs access to the national electricity grid and simplify the application process

Emergent view 4f: In South Africa a WTE industry must be subsidised (with applicable ies) to kick start investor interest.

There is consensus that the true cost of disposal is not realised in South Africa, largely due to cheap and abundant land. It negatively impacts on the financial feasibility of a WTE 
plant which will also require a gate fee to be cost-effective. Generally interviewees do not support inflating the price of disposal but recognise that the proposed pricing strategy is likely to result in a waste management cost increase. An electricity price hike is not supported and especially not in the interest of financially supporting a non-existent WTE industry. There is however support for the introduction of cleaner electricity into the market in the form of green energy. Generally respondents did not favour the idea of a production levy. The ideal of a self-sustaining WTE especially in relation to the financial feasibility was generally preferred. This is a novel idea and interviewees did not comment with confidence. Some agreed but most did not support the idea of creating a funding opportunity for WTE through this mechanism. There is overwhelming consensus that access to the electricity grid must be less onerous, but most interviewees shares the sentiment that it appears as if Eskom (maybe in partnership with the government) is resisting the entry of IPPP's into its market. The reason for Eskom's position in this regard is not known nor will it be further discussed in this study (outside of scope). Subsidising the WTE was put forward as a necessary intervention needed for WTE, however most interviewees prefers to introduce a stand-alone WTE industry able to sustain itself financially given that the technology is proven and therefore is not a limiting factor.

Table 3: Summary of Industry expert opinions on emerging views

\begin{tabular}{|c|c|c|c|c|c|c|c|c|c|c|c|}
\hline \multirow{2}{*}{$\begin{array}{l}\text { Emergi } \\
\text { ng } \\
\text { view }\end{array}$} & \multicolumn{11}{|c|}{ Interviewee nr } \\
\hline & 1 & 2 & 3 & 4 & 5 & 6 & 7 & 8 & 9 & 10 & 11 \\
\hline $1 a$ & Agree & Agree & Agree & $\begin{array}{l}\text { No } \\
\text { comm } \\
\text { ent }\end{array}$ & Agree & $\begin{array}{l}\text { No } \\
\text { comm } \\
\text { ent }\end{array}$ & Agree & $\begin{array}{l}\text { No } \\
\text { comme } \\
\text { nt }\end{array}$ & $\begin{array}{l}\text { No } \\
\text { comme } \\
\text { nt }\end{array}$ & Agree & $\begin{array}{l}\text { No } \\
\text { comm } \\
\text { ent }\end{array}$ \\
\hline 1b & $\begin{array}{l}\text { No } \\
\text { comm } \\
\text { ent }\end{array}$ & $\begin{array}{l}\text { No } \\
\text { comm } \\
\text { ent }\end{array}$ & Agree & $\begin{array}{l}\text { No } \\
\text { comm } \\
\text { ent }\end{array}$ & Agree & $\begin{array}{l}\text { No } \\
\text { comm } \\
\text { ent }\end{array}$ & Agree & $\begin{array}{l}\text { No } \\
\text { comme } \\
\text { nt }\end{array}$ & $\begin{array}{l}\text { No } \\
\text { comme } \\
\text { nt }\end{array}$ & Agree & Agree \\
\hline $2 a$ & $\begin{array}{l}\text { No } \\
\text { comm } \\
\text { ent }\end{array}$ & Agree & $\begin{array}{l}\text { No } \\
\text { comm } \\
\text { ent }\end{array}$ & Agree & $\begin{array}{l}\text { No } \\
\text { comm } \\
\text { ent }\end{array}$ & $\begin{array}{l}\text { No } \\
\text { comm } \\
\text { ent }\end{array}$ & Agree & Agree & Agree & Agree & $\begin{array}{l}\text { No } \\
\text { comm } \\
\text { ent }\end{array}$ \\
\hline $2 b$ & $\begin{array}{l}\text { No } \\
\text { comm } \\
\text { ent }\end{array}$ & Agree & $\begin{array}{l}\text { No } \\
\text { comm } \\
\text { ent }\end{array}$ & Agree & $\begin{array}{l}\text { No } \\
\text { comm } \\
\text { ent }\end{array}$ & Agree & $\begin{array}{l}\text { No } \\
\text { comme } \\
\text { nt }\end{array}$ & $\begin{array}{l}\text { No } \\
\text { comme } \\
\text { nt }\end{array}$ & Agree & $\begin{array}{l}\text { No } \\
\text { comm } \\
\text { ent }\end{array}$ & $\begin{array}{l}\text { No } \\
\text { comm } \\
\text { ent }\end{array}$ \\
\hline 2c & Agree & Agree & Agree & Agree & Agree & Agree & Agree & Agree & Agree & Agree & Agree \\
\hline $3 a$ & $\begin{array}{l}\text { Disagr } \\
\text { ee }\end{array}$ & Agree & Agree & Agree & Agree & Agree & Agree & Agree & $\begin{array}{l}\text { Disagr } \\
\text { ee }\end{array}$ & $\begin{array}{l}\text { Disagr } \\
\text { ee }\end{array}$ & Agree \\
\hline $3 b$ & $\begin{array}{l}\text { No } \\
\text { comm } \\
\text { ent }\end{array}$ & Agree & Agree & Agree & Agree & Agree & Agree & Agree & $\begin{array}{l}\text { No } \\
\text { comme } \\
\text { nt }\end{array}$ & Agree & Agree \\
\hline $3 c$ & Agree & Agree & Agree & $\begin{array}{l}\text { No } \\
\text { comm } \\
\text { ent }\end{array}$ & Agree & Agree & Agree & Agree & $\begin{array}{l}\text { No } \\
\text { comme } \\
\text { nt }\end{array}$ & Agree & Agree \\
\hline 3d & Agree & Agree & Agree & $\begin{array}{l}\text { No } \\
\text { comm } \\
\text { ent }\end{array}$ & Agree & Agree & Agree & Agree & Agree & Agree & Agree \\
\hline $3 e$ & Agree & Agree & Agree & Agree & Agree & Agree & Agree & Agree & Agree & Agree & Agree \\
\hline $3 f$ & Agree & Agree & Agree & $\begin{array}{l}\text { Disagr } \\
\text { ee }\end{array}$ & Agree & $\begin{array}{l}\text { No } \\
\text { comm } \\
\text { ent }\end{array}$ & $\begin{array}{l}\text { No } \\
\text { comm } \\
\text { ent }\end{array}$ & Agree & $\begin{array}{l}\text { No } \\
\text { comme } \\
\text { nt }\end{array}$ & $\begin{array}{l}\text { No } \\
\text { comm } \\
\text { ent }\end{array}$ & $\begin{array}{l}\text { Disagr } \\
\text { ee }\end{array}$ \\
\hline $3 g$ & Agree & $\begin{array}{l}\text { Disagr } \\
\text { ee }\end{array}$ & Agree & Agree & $\begin{array}{l}\text { Disagr } \\
\text { ee }\end{array}$ & Agree & Agree & Agree & Agree & Agree & $\begin{array}{l}\text { Disagr } \\
\text { ee }\end{array}$ \\
\hline $4 a$ & Agree & Agree & $\begin{array}{l}\text { No } \\
\text { comm } \\
\text { ent }\end{array}$ & Agree & $\begin{array}{l}\text { Disagr } \\
\text { ee }\end{array}$ & $\begin{array}{l}\text { Disagr } \\
\text { ee }\end{array}$ & Agree & $\begin{array}{l}\text { Disagre } \\
\mathrm{e}\end{array}$ & $\begin{array}{l}\text { Disagre } \\
\text { ed }\end{array}$ & $\begin{array}{l}\text { No } \\
\text { comm } \\
\text { ent }\end{array}$ & $\begin{array}{l}\text { Disagr } \\
\text { ee }\end{array}$ \\
\hline $4 b$ & $\begin{array}{l}\text { Disagr } \\
\text { ee }\end{array}$ & Agree & Agree & Agree & Agree & Agree & $\begin{array}{l}\text { No } \\
\text { comme } \\
\text { nt }\end{array}$ & Agree & Agree & $\begin{array}{l}\text { Disagr } \\
\text { ee }\end{array}$ & $\begin{array}{l}\text { No } \\
\text { comm } \\
\text { ent }\end{array}$ \\
\hline $4 c$ & Agree & Agree & $\begin{array}{l}\text { No } \\
\text { comm } \\
\text { ent }\end{array}$ & $\begin{array}{l}\text { No } \\
\text { comm } \\
\text { ent }\end{array}$ & Agree & Agree & Agree & $\begin{array}{l}\text { Disagre } \\
\text { ed }\end{array}$ & $\begin{array}{l}\text { No } \\
\text { comme } \\
\text { nt }\end{array}$ & $\begin{array}{l}\text { No } \\
\text { comm } \\
\text { ent }\end{array}$ & Agree \\
\hline 4d & $\begin{array}{l}\text { Disagr } \\
\text { ee }\end{array}$ & $\begin{array}{l}\text { Disagr } \\
\text { ee }\end{array}$ & Agree & $\begin{array}{l}\text { No } \\
\text { comm }\end{array}$ & Agree & Agree & Agree & Agree & Agree & $\begin{array}{l}\text { No } \\
\text { comm }\end{array}$ & $\begin{array}{l}\text { No } \\
\text { comm }\end{array}$ \\
\hline
\end{tabular}




\begin{tabular}{|l|l|l|l|l|l|l|l|l|l|l|}
\hline & & & & ent & & & & ent & ent \\
\hline $\mathbf{4 e}$ & Agree & Agree & Agree & $\begin{array}{l}\text { No } \\
\text { comm } \\
\text { ent }\end{array}$ & $\begin{array}{l}\text { No } \\
\text { comm } \\
\text { ent }\end{array}$ & Agree & Agree & Agree & $\begin{array}{l}\text { Agree } \\
\text { comm } \\
\text { ent }\end{array}$ & $\begin{array}{l}\text { No } \\
\text { comm } \\
\text { ent }\end{array}$ \\
\hline $\mathbf{4 f}$ & Agree & Agree & $\begin{array}{l}\text { No } \\
\text { comm } \\
\text { ent }\end{array}$ & $\begin{array}{l}\text { disagr } \\
\text { ee }\end{array}$ & $\begin{array}{l}\text { No } \\
\text { comm } \\
\text { ent }\end{array}$ & Agree & Agree & $\begin{array}{l}\text { Disagre } \\
\text { e }\end{array}$ & $\begin{array}{l}\text { Agree } \\
\text { comm } \\
\text { ent }\end{array}$ \\
\hline
\end{tabular}

\subsection{Second round analysis}

A total of 6 respondents whom were also interviewees during the $1^{\text {st }}$ round, were requested to rank these barriers in order of relevance. The outcome of this investigation is summarised in the Table 4 below, and is measured between 1 and 8 , where 1 is most and 8 least relevant. There is convergence between respondents on these barriers. Some descriptive statistics (median and mode) were used to analyse this data.

Table 4: Proposed barriers ranked by 6 respondents in terms of relevance

\begin{tabular}{|c|c|c|c|c|c|}
\hline $\begin{array}{l}\text { Proposed } \\
\text { barriers }\end{array}$ & Respondent & Relevance & Median & Mode & Comments \\
\hline \multirow{6}{*}{$\begin{array}{l}\text { Low cost of } \\
\text { landfilling }\end{array}$} & Respondent 1 & 2 & \multirow[t]{6}{*}{2.5} & \multirow[t]{6}{*}{1 and 3} & \multirow{6}{*}{$\begin{array}{l}\text { The set of data is bi-modal } \\
\text { and a mode of } 1 \text { and } 3 \text { is } \\
\text { presented. Regardless the } \\
\text { median and the mode are } \\
\text { very close to each other. } \\
\text { Overall this barrier is } \\
\text { ranked as the } \mathbf{2}^{\text {nd }} \text { most } \\
\text { relevant }\end{array}$} \\
\hline & Respondent 2 & 4 & & & \\
\hline & Respondent 3 & 3 & & & \\
\hline & Respondent 4 & 1 & & & \\
\hline & Respondent 5 & 1 & & & \\
\hline & Respondent 6 & 3 & & & \\
\hline \multirow{6}{*}{$\begin{array}{l}\text { No landfill } \\
\text { taxes (linked to } \\
\text { low cost of } \\
\text { landfilling) }\end{array}$} & Respondent 1 & 3 & \multirow[t]{6}{*}{4} & \multirow[t]{6}{*}{2 and 5} & \multirow{6}{*}{$\begin{array}{l}\text { The set of data is bi-modal } \\
\text { and a mode of } 2 \text { and } 5 \text { is } \\
\text { presented. Regardless the } \\
\text { median and the mode are } \\
\text { very close to each other. } \\
\text { Overall this barrier is } \\
\text { ranked as the } 4^{\text {th }} \text { most } \\
\text { relevant }\end{array}$} \\
\hline & Respondent 2 & 5 & & & \\
\hline & Respondent 3 & 6 & & & \\
\hline & Respondent 4 & 2 & & & \\
\hline & Respondent 5 & 2 & & & \\
\hline & Respondent 6 & 5 & & & \\
\hline \multirow{6}{*}{$\begin{array}{l}\text { Cheap and } \\
\text { readily } \\
\text { available coal }\end{array}$} & Respondent 1 & 1 & \multirow[t]{6}{*}{1.5} & \multirow[t]{6}{*}{1} & \multirow{6}{*}{$\begin{array}{l}\text { The median and the mode } \\
\text { are very close to each } \\
\text { other. } \\
\text { Overall this barrier is } \\
\text { ranked as the most relevant } \\
\left(\mathbf{1}^{\text {st }}\right)\end{array}$} \\
\hline & Respondent 2 & 2 & & & \\
\hline & Respondent 3 & 1 & & & \\
\hline & Respondent 4 & 3 & & & \\
\hline & Respondent 5 & 3 & & & \\
\hline & Respondent 6 & 1 & & & \\
\hline \multirow{6}{*}{$\begin{array}{l}\text { Lack of } \\
\text { support from } \\
\text { government }\end{array}$} & Respondent 1 & 4 & \multirow[t]{6}{*}{3} & \multirow[t]{6}{*}{2 and 4} & \multirow{6}{*}{$\begin{array}{l}\text { The set of data is bi-modal } \\
\text { and a mode of } 2 \text { and } 4 \text { is } \\
\text { presented. Regardless the } \\
\text { median and the mode are } \\
\text { very close to each other. } \\
\text { Overall this barrier is } \\
\text { ranked as the } \mathbf{3}^{\text {rd }} \text { most } \\
\text { relevant }\end{array}$} \\
\hline & Respondent 2 & 1 & & & \\
\hline & Respondent 3 & 2 & & & \\
\hline & Respondent 4 & 4 & & & \\
\hline & Respondent 5 & 5 & & & \\
\hline & Respondent 6 & 2 & & & \\
\hline \multirow{3}{*}{$\begin{array}{l}\text { Absence of a } \\
\text { carbon tax } \\
\text { (linked to } \\
\text { government }\end{array}$} & Respondent 1 & 7 & \multirow[t]{3}{*}{7} & \multirow[t]{3}{*}{7} & \multirow{2}{*}{$\begin{array}{l}\text { The median and the mode } \\
\text { are similar values. }\end{array}$} \\
\hline & Respondent 2 & 8 & & & \\
\hline & Respondent 3 & 7 & & & Overall this barrier is \\
\hline
\end{tabular}




\begin{tabular}{|c|c|c|c|c|c|}
\hline \multirow[t]{3}{*}{ support) } & Respondent 4 & 7 & & & \multirow{3}{*}{$\begin{array}{l}\text { ranked as the } 7^{\text {th }} \text { most } \\
\text { relevant. }\end{array}$} \\
\hline & Respondent 5 & 8 & & & \\
\hline & Respondent 6 & 4 & & & \\
\hline \multirow{6}{*}{$\begin{array}{l}\text { Securing } \\
\text { feedstock }\end{array}$} & Respondent 1 & 6 & \multirow[t]{6}{*}{5.5} & \multirow[t]{6}{*}{5 and 7} & \multirow{6}{*}{$\begin{array}{l}\text { The set of data is bi-modal } \\
\text { and a mode of } 5 \text { and } 7 \text { is } \\
\text { presented. Regardless the } \\
\text { median and the mode are } \\
\text { very close to each other. } \\
\text { Overall it appears if this } \\
\text { barrier is ranked as the } \\
5^{\text {th } \text { most relevant }}\end{array}$} \\
\hline & Respondent 2 & 7 & & & \\
\hline & Respondent 3 & 5 & & & \\
\hline & Respondent 4 & 5 & & & \\
\hline & Respondent 5 & 4 & & & \\
\hline & Respondent 6 & 7 & & & \\
\hline \multirow{6}{*}{$\begin{array}{l}\text { Lack of public } \\
\text { awareness, and }\end{array}$} & Respondent 1 & 8 & \multirow[t]{6}{*}{8} & \multirow[t]{6}{*}{8} & \multirow{6}{*}{$\begin{array}{l}\text { The median and the mode } \\
\text { are similar } \\
\text { Overall this barrier is } \\
\text { ranked as the } \mathbf{8}^{\text {th }} \text { most } \\
\text { relevant }\end{array}$} \\
\hline & Respondent 2 & 6 & & & \\
\hline & Respondent 3 & 8 & & & \\
\hline & Respondent 4 & 8 & & & \\
\hline & Respondent 5 & 7 & & & \\
\hline & Respondent 6 & 8 & & & \\
\hline \multirow{6}{*}{$\begin{array}{l}\text { Access to the } \\
\text { national } \\
\text { electricity grid }\end{array}$} & Respondent 1 & 5 & \multirow[t]{6}{*}{5.5} & \multirow[t]{6}{*}{6} & \multirow{6}{*}{$\begin{array}{l}\text { The median and the mode } \\
\text { are very close to each } \\
\text { other. } \\
\text { Overall this barrier is } \\
\text { ranked as the } \mathbf{6}^{\text {th }} \text { most } \\
\text { relevant }\end{array}$} \\
\hline & Respondent 2 & 3 & & & \\
\hline & Respondent 3 & 4 & & & \\
\hline & Respondent 4 & 6 & & & \\
\hline & Respondent 5 & 6 & & & \\
\hline & Respondent 6 & 6 & & & \\
\hline
\end{tabular}

There are consensus between the respondents that cheap coal and cheap landfilling hinders the establishment of a WTE industry. The respondents are also in agreement that public awareness does not play that big a role, nor the implementation of a carbon tax.

\section{Discussion and Conclusion}

The electricity generation mix in South Africa is predominantly built on coal as the primary fuel source and up to now little attempt has been made to evolve into alternatives apart from nuclear and off late renewable energy (solar, hydro and wind). Numerous incidences of a shortfall in electricity generation capacity have been experienced that gave rise to periods of load shedding. Diversification of the South African electricity generation mix towards WTE has been slow compared to the rapid pace at which this energy source has been introduced in the European Union (EU). There are a number of key differences that exists between South Africa and Europe. This study set out to highlight these differences with the objective to leverage the European model to inform the establishment of a sustainable South African WTE industry.

Europe had to overcome several limitations in order to steer them into WTE as a viable alternative. Shortage of cheap and available land was one such constraint. A waste management solution was needed that consumes a smaller footprint and avoid hauling waste for long distances. In addition the public expresses support for the thermal destruction of waste given the guarantee of a secure supply of electricity at reasonable prices. In contrast South Africa has an abundance of land available and its economy needs cheap electricity to achieve the growth needed to support the population's needs.

The EU made a conscious decision through legislative instruments to push member states towards WTE as a waste management solution. The analysis of data gathered for this investigation strongly put forward that South Africa has the legislative framework in place 
to divert waste away from landfills but that enforcement lacks; however the respondents generally preferred recycling to WTE.

Most European countries further created an environment conducive for WTE by escalating the cost to landfill waste through the introduction of a landfill tax. In many instances the tax portion of the gate fee was more than the cost of disposal. This essentially pushed the avoidance of waste disposal to land aiding in feedstock security. Generally in the South African context the true cost of disposing waste to landfill is not fully understood by municipalities as well as the SA population (who is not paying proportionately for the service rendered by local authorities). A shortage of land, legislation together with the adjustment in the cost to landfill waste enabled the European WTE industry and resulted in a secure feedstock available to WTE. This created a foundation to attract private investments towards WTE activating rapid growth in the industry. Although there is agreement that the true cost for disposal is not realised in South Africa and is therefore a barrier to a WTE industry, the data analysis suggests that inflating the cost for disposal will not be effective in the South African context. Prior to any such measure a shift in mind-set of the general public towards the negative cost associated with waste disposal is required. Therefore there is little to no guarantee of a secure feedstock (waste) that will be directed to a WTE facility which will need to charge a gate fee at a much higher premium compared to current landfill rates. The data analysis does however support the introduction of a landfill tax to reduce waste to land and channel the waste into more economically beneficial schemes such as WTE.

The low cost of coal fired electricity (identified as a barrier) is an element that was discussed to improve the economics of a WTE industry. However, increasing the price coal fired grid connected electricity it is not advised from a socio-economic perspective, since the vulnerable portion of the population is likely to feel the brunt of such increase. The logical option would be to have WTE economically competitive (while creating the options for co-combustion \& co-generation) at a localised scale. While co-combustion and co-gasification in existing coal power plants would mean a range benefits (Psomopoulos and Themelis, 2015) the likelihood of such occurring in South Africa is limited because of the monopolistic nature of South Africa's grid infrastructure maintained by South Africa's single electricity utility, Eskom (Khan et al., 2016). This sentiment is corroborated by the feedback received from industry experts within this study. In order to maximise the benefits, IPPPs should have access to grid infrastructure and be willing to share the cost of maintenance of the infrastructure. The data analysis clearly highlights that the process to access the grid must be streamlined and support given by government to IPPPs. Further a lack of support for WTE from government where highlighted as a barrier.

Though the WTE industry provides a range of socio-economic benefits not just for developing countries (Psomopoulos and Themelis, 2014); (Psomopoulos et al., 2014) the situation in South Africa is slightly complex as a result of the importance of coal. Coal mining is a major foreign exchange supplier for South Africa, contributing 51billion ZAR compared to gold which contributed 31billion ZAR, during the year 2013 (Statistics SA, 2015). From a social perspective, the coal mining industry employees more than 91000 individuals which is almost $17 \%$ of the total mining workforce. Therefore to create socioeconomic benefits in South Africa from WTE, a structured and formal WTE industry with adequate waste collection and recycling streams have to be developed, while gradually reducing the dependency on coal. These benefits will be in addition to the benefits related to reduced GHG emissions (Psomopoulos, 2014) which can achieved by reducing the amount of landfill. A detailed investigation of the cost-benefits related to GHG mitigation for South Africa on a national scale, which extends beyond policy measures would be required as continuation. 
Government intervention (through subsidies \& recycling interventions) is considered very important especially in the early stages of a WTE industry's life cycle to get it going. Government's lack of appetite is therefore currently hindering the establishment of a WTE industry and the inclusion of WTE within the strategic energy roadmap is proposed. The barriers to a WTE industry were confirmed, however the enablers were revised based on this research's outcome. Based on this a revised model to enable a South Africa WTE industry is presented in figure 4 . In addition an improved recycling efficiency, subsidising the WTE industry (in the beginning only) and including WTE as a source of electricity in the long term planning is called for. A hike of electricity prices, public acceptance and production taxes were not seen as viable enablers in support of a WTE industry.
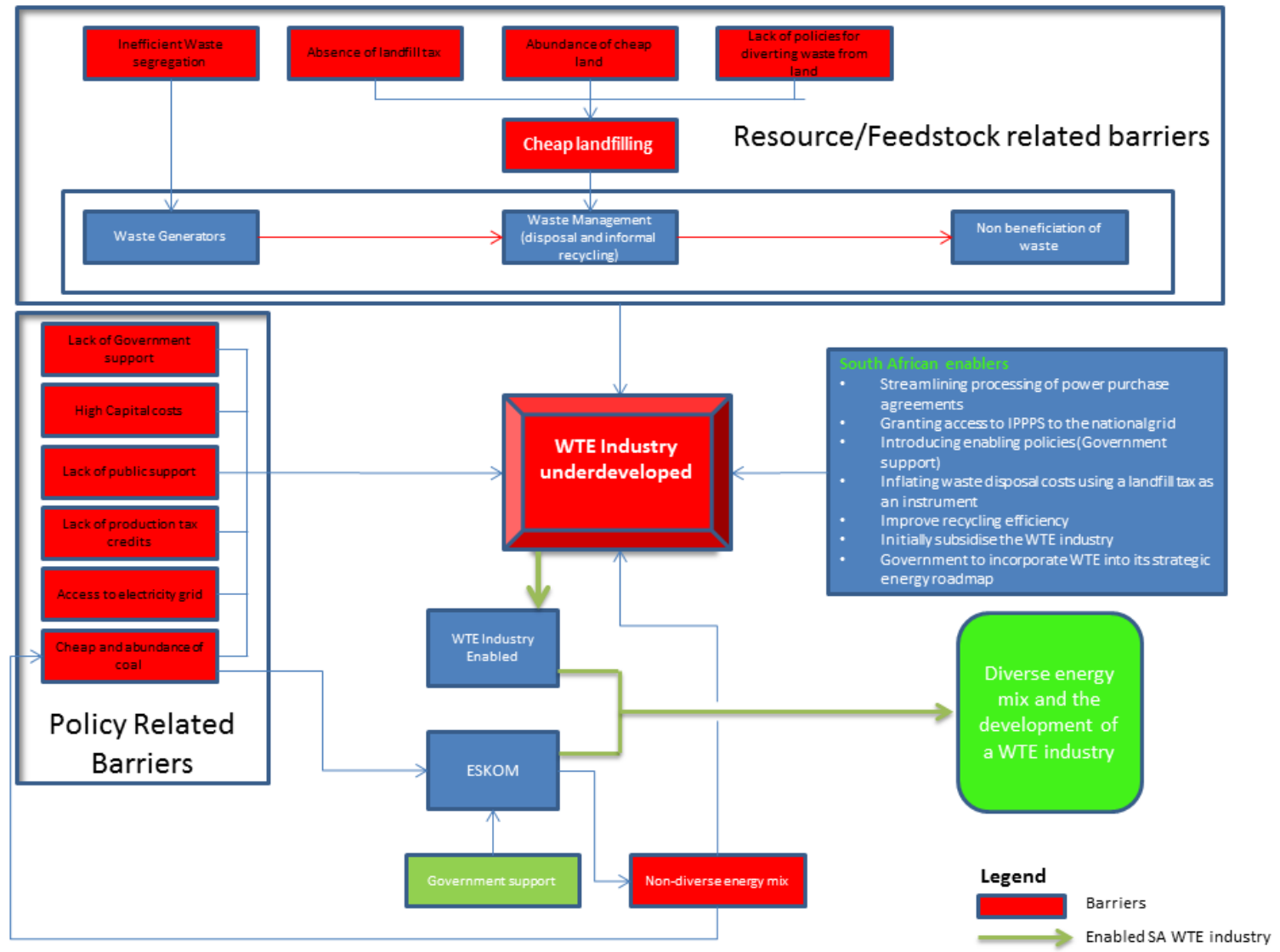

\section{Figure 4: Recommended model for South Africa to enable a waste to energy industry}

In conclusion, the development of the WTE is dependent on how landfill and carbon taxes will evolve in South Africa. Though land is generally abundant in South Africa, a lack of available land in cities and metropolitan areas will be one incentive for increasing landfill taxes. Doing so would alleviate pressures on the rising waste streams caused by migration from rural parts of the country, which is a characteristic in developing countries. The secondary reason will be based on the environmental costs and benefits that arise from shifting away from landfills. However this would require additional quantitative investigation on a municipal and national level and the findings from such studies would act as an add-on for any policy based interventions. Such cost-benefit investigations will also aid in determining the level of subsidies required for a nascent WTE industry. The impending implementation of a carbon tax will also have to be taken into consideration as part of the cost-benefit analysis. 


\section{References}

Ahlborg, H., Hammar, L., 2014. Drivers and barriers to rural electrification in tanzania and mozambique - grid-extension, off-grid, and renewable energy technologies. Renew. Energy 61, 117-124. doi:10.1016/j.renene.2012.09.057

Altinay, G., Karagol, E., 2005. Electricity consumption and economic growth: Evidence from Turkey. Energy Econ. 27, 849-856. doi:10.1016/j.eneco.2005.07.002

Ang, B.W., Su, B., 2016. Carbon emission intensity in electricity production: A global analysis. Energy Policy 94. doi:10.1016/j.enpol.2016.03.038

Armaroli, N., Balzani, V., 2011. Towards an electricity-powered world. Energy Environ. Sci. 4, 3193. doi:10.1039/c1ee01249e

Aslani, A., Naaranoja, M., Zakeri, B., 2012. The prime criteria for private sector participation in renewable energy investment in the Middle East (case study: Iran). Renew. Sustain. Energy Rev. 16, 1977-1987. doi:10.1016/j.rser.2011.12.015

Assamoi, B., Lawryshyn, Y., 2012. The environmental comparison of landfilling vs. incineration of MSW accounting for waste diversion. Waste Manag. 32, 1019-1030. doi:10.1016/j.wasman.2011.10.023

Atlas.ti [WWW Document], 2016.

Balachandra, P., 2006. Implications of private sector participation in power generation-a case study from India. Energy Policy 34, 2466-2479. doi:10.1016/j.enpol.2004.08.014

Balat, M., 2006. Electricity from Worldwide Energy Sources. Energy Sources, Part B Econ. Planning, Policy 1, 395-412. doi:10.1080/15567240500400879

Baxter, J., Ho, Y., Rollins, Y., Maclaren, V., 2016. Attitudes toward waste to energy facilities and impacts on diversion in Ontario, Canada. Waste Manag. 50, 75-85. doi:10.1016/j.wasman.2016.02.017

Bidart, C., Fröhling, M., Schultmann, F., 2013. Municipal solid waste and production of substitute natural gas and electricity as energy alternatives. Appl. Therm. Eng. 51, 1107-1115. doi:10.1016/j.applthermaleng.2012.10.021

Brunner, P.H., Rechberger, H., 2015. Waste to energy - key element for sustainable waste management. Waste Manag. 37, 3-12. doi:10.1016/j.wasman.2014.02.003

De Feo, G., De Gisi, S., Williams, I.D., 2013. Public perception of odour and environmental pollution attributed to MSW treatment and disposal facilities: A case study. Waste Manag. 33, 974-987. doi:10.1016/j.wasman.2012.12.016

Department of Environmental Affairs, 2012. National Waste Information Baseline Report. Pretoria, South Africa.

EEA, 2014. Typical charge (gate fee and landfill tax) for legal landfilling of non-hazardous municipal waste in EU Member States and regions - European Environment Agency (EEA).

EIA, 2016. International Energy Outlook 2016.

Eskom, 2015. Integrated annual report, Integrated Annual Report 2015. Sandton, South Africa.

Fatai, K., Oxley, L., Scrimgeour, F.G., 2004. Modelling the causal relationship between energy consumption and GDP in New Zealand, Australia, India, Indonesia, The Philippines and Thailand. Math. Comput. Simul. 64, 431-445. doi:10.1016/S03784754(03)00109-5

Godfrey, L., 2008. Facilitating the improved management of waste in South Africa through a national waste information system. Waste Manag. 28, 1660-1671. doi:10.1016/j.wasman.2007.06.002

Green Cape, 2015. Waste Economy, 2015, Market Intelligence Report.

Guerrero, L.A., Maas, G., Hogland, W., 2013. Solid waste management challenges for cities in developing countries. Waste Manag. 33, 220-232. doi:10.1016/j.wasman.2012.09.008

Habib, K., Schmidt, J.H., Christensen, P., 2013. A historical perspective of Global Warming Potential from Municipal Solid Waste Management. Waste Manag. 33, 1926-1933. doi:10.1016/j.wasman.2013.04.016 
Hartenstein, H.U., Horvay, M., 1996. Overview of municipal waste incineration industry in west Europe (based on the German experience). J. Hazard. Mater. 47, 19-30. doi:10.1016/0304-3894(95)00124-7

Heffron, R.J., 2013. Nuclear new build in the United States 1990-2010: A three state analysis. Technol. Forecast. Soc. Change 80, 876-892. doi:10.1016/j.techfore.2012.10.023

Hoornweg, D., Bhada-Tata, P., 2012. A Global Review of Solid Waste Management. Washington DC, USA.

Infrastructure News, 2016. Fuelling the waste revolution [WWW Document]. Infrastucturene.ws. URL http://www.infrastructurene.ws/2016/12/07/fuelling-thewaste-revolution/ (accessed 6.2.17).

Inglesi, R., 2010. Aggregate electricity demand in South Africa: Conditional forecasts to 2030. Appl. Energy 87, 197-204. doi:10.1016/j.apenergy.2009.08.017

Jamel, M.S., Abd Rahman, A., Shamsuddin, A.H., 2013. Advances in the integration of solar thermal energy with conventional and non-conventional power plants. Renew. Sustain. Energy Rev. 20, 71-81. doi:10.1016/j.rser.2012.10.027

Keho, Y., 2016. What drives energy consumption in developing countries? The experience of selected African countries. Energy Policy 91, 233-246. doi:10.1016/j.enpol.2016.01.010

Khan, M.T., Thopil, G.A., Lalk, J., 2016. Review of proposals for practical power sector restructuring and reforms in a dynamic electricity supply industry. Renew. Sustain. Energy Rev. 62. doi:10.1016/j.rser.2016.04.056

Krupa, J., Burch, S., 2011. A new energy future for South Africa: The political ecology of South African renewable energy. Energy Policy 39, 6254-6261. doi:10.1016/j.enpol.2011.07.024

Linda Godfrey, Strydom, W., Muswema, A., Oelofse, S., Roman, H., Mange, M., Nienaber, S., 2013. South African Waste Sector - 2012: An analysis of the formal private and public waste sectors in South Africa. A National Waste RDI Roadmap for South Africa: Phase 1 Status Quo Assessment. 48.

Lino, F.A.M., Ismail, K.A.R., 2011. Energy and environmental potential of solid waste in Brazil. Energy Policy 39, 3496-3502. doi:10.1016/j.enpol.2011.03.048

Massarutto, A., 2015. Economic aspects of thermal treatment of solid waste in a sustainable WM system. Waste Manag. 37, 45-57. doi:10.1016/j.wasman.2014.08.024

Matete, N., Trois, C., 2008. Towards Zero Waste in emerging countries - A South African experience. Waste Manag. 28, 1480-1492. doi:10.1016/j.wasman.2007.06.006

McDaid, L., 2014. Renewable Energy Independent Power Producer Procurement Programme Review.

Melikoglu, M., 2013. Vision 2023: Assessing the feasibility of electricity and biogas production from municipal solid waste in Turkey. Renew. Sustain. Energy Rev. 19, 52-63. doi:10.1016/j.rser.2012.11.017

Menikpura, S.N.M., Sang-Arun, J., Bengtsson, M., 2016. Assessment of environmental and economic performance of Waste-to-Energy facilities in Thai cities. Renew. Energy 86, 576-584. doi:10.1016/j.renene.2015.08.054

Miranda, M.L., Hale, B., 1997. Waste not, want not: the private and social costs of wasteto-energy production. Energy Policy 25, 587-600. doi:10.1016/S03014215(97)00050-5

Monni, S., 2012. From landfilling to waste incineration: Implications on GHG emissions of different actors. Int. J. Greenh. Gas Control 8, 82-89. doi:10.1016/j.ijggc.2012.02.003

Münster, M., Meibom, P., 2011. Optimization of use of waste in the future energy system. Energy 36, 1612-1622. doi:10.1016/j.energy.2010.12.070

Nahman, A., 2011. Pricing landfill externalities: Emissions and disamenity costs in Cape Town, South Africa. Waste Manag. 31, 2046-2056. doi:10.1016/j.wasman.2011.05.015

Nahman, A., Godfrey, L., 2010. Economic instruments for solid waste management in 
South Africa: Opportunities and constraints. Resour. Conserv. Recycl. 54, 521-531. doi:10.1016/j.resconrec.2009.10.009

Odhiambo, N.M., 2010. Energy consumption, prices and economic growth in three SSA countries: A comparative study. Energy Policy 38, 2463-2469. doi:10.1016/j.enpol.2009.12.040

Odhiambo, N.M., 2009. Electricity consumption and economic growth in South Africa: A trivariate causality test. Energy Econ. 31, 635-640. doi:10.1016/j.eneco.2009.01.005

Ofori-Boateng, C., Lee, K.T., Mensah, M., 2013. The prospects of electricity generation from municipal solid waste (MSW) in Ghana: A better waste management option. Fuel Process. Technol. doi:10.1016/j.fuproc.2012.11.008

Ouda, O.K.M., Cekirge, H.M., Raza, S.A.R., 2013. An assessment of the potential contribution from waste-to-energy facilities to electricity demand in Saudi Arabia. Energy Convers. Manag. 75, 402-406. doi:10.1016/j.enconman.2013.06.056

Pavlas, M., Tous, M., Bébar, L., Stehlík, P., 2010. Waste to energy An evaluation of the environmental impact. Appl. Therm. Eng. 30, 2326-2332. doi:10.1016/j.applthermaleng.2009.10.019

Pavlović, T.M., Radonjić, I.S., Milosavljević, D.D., Pantić, L.S., 2012. A review of concentrating solar power plants in the world and their potential use in Serbia. Renew. Sustain. Energy Rev. 16, 3891-3902. doi:10.1016/j.rser.2012.03.042

Pazheri, F.R., Othman, M.F., Malik, N.H., 2014. A review on global renewable electricity scenario. Renew. Sustain. Energy Rev. 31, 835-845. doi:10.1016/j.rser.2013.12.020

Pegels, A., 2010. Renewable energy in South Africa: Potentials, barriers and options for support. Energy Policy 38, 4945-4954. doi:10.1016/j.enpol.2010.03.077

Powell, C., 2003. The Delphi technique: myths and realities. J Adv.Nurs. 41, 376-382.

Psomopoulos, C.S., 2014. Residue Derived Fuels as an Alternative Fuel for the Hellenic Power Generation Sector and their Potential for Emissions Reduction. AIMS Energy 2, 321-341. doi:10.3934/energy.2014.3.321

Psomopoulos, C.S., Bourka, A., Themelis, N.J., 2009. Waste-to-energy: A review of the status and benefits in USA. Waste Manag. 29, 1718-1724. doi:10.1016/j.wasman.2008.11.020

Psomopoulos, C.S., Themelis, N.J., 2015. The Combustion of As-received and Preprocessed (RDF/SRF) Municipal Solid Wastes as Fuel for the Power Sector. Energy Sources, Part A Recover. Util. Environ. Eff. 37, 1813-1820. doi:10.1080/15567036.2011.639845

Psomopoulos, C.S., Themelis, N.J., 2014. A Guidebook for Sustainable Waste Management in Latin America, in: International Resource Recovery Congress Wasteto-Energy.

Psomopoulos, C.S., Venetis, I., Themelis, N.J., 2014. The impact from the implementation of "Waste to Energy" to the economy. A macroeconomic approach for the trade balance of Greece. Fresenius Environ. Bull. 23, 2735-2741.

Ramírez-Camperos, A.M., Rodríguez-Padilla, V., Guido-Aldana, P.A., 2013. The Mexican electricity sector: Policy analysis and reform (1992-2009). Energy Policy 62, 10921103. doi:10.1016/j.enpol.2013.06.063

Rogge, K.S., Schneider, M., Hoffmann, V.H., 2011. The innovation impact of the EU Emission Trading System - Findings of company case studies in the German power sector. Ecol. Econ. 70, 513-523. doi:10.1016/j.ecolecon.2010.09.032

Ruth, L.A., 1998. Energy From Municipal Solid Waste: a Comparison With Coal Combustion Technology. Prog. Energy Combust. Sci. 24, 545-564.

Ruuska, I., Ahola, T., Artto, K., Locatelli, G., Mancini, M., 2011. A new governance approach for multi-firm projects: Lessons from Olkiluoto 3 and Flamanville 3 nuclear power plant projects. Int. J. Proj. Manag. 29, 647-660. doi:10.1016/j.ijproman.2010.10.001

Saidur, R., Abdelaziz, E.A., Demirbas, A., Hossain, M.S., Mekhilef, S., 2011. A review on biomass as a fuel for boilers. Renew. Sustain. Energy Rev. 15, 2262-2289. doi:10.1016/j.rser.2011.02.015 
Sebitosi, A.B., Pillay, P., 2008. Renewable energy and the environment in South Africa: A way forward. Energy Policy 36, 3312-3316. doi:10.1016/j.enpol.2008.05.013

Statistics SA, 2015. The importance of coal [WWW Document]. URL http://www.statssa.gov.za/?p=4820 (accessed 6.3.17).

Teixeira, S., Monteiro, E., Silva, V., Rouboa, A., 2014. Prospective application of municipal solid wastes for energy production in Portugal. Energy Policy 71, 159-168. doi:10.1016/j.enpol.2014.04.002

Thopil, G.A., Pouris, A., 2015. Aggregation and internalisation of electricity externalities in South Africa. Energy 82, 501-511. doi:10.1016/j.energy.2015.01.059

Trois, C., Simelane, O.T., 2010. Implementing separate waste collection and mechanical biological waste treatment in South Africa: A comparison with Austria and England. Waste Manag. 30, 1457-1463. doi:10.1016/j.wasman.2009.12.020

Williams, M., 2011. Waste-to-Energy Success Factors in Sweden and The United States: Analysing the Transferability of The Swedish Waste-to-Energy Model to The United States 23.

Yoo, Ã.S., 2006. The causal relationship between electricity consumption and economic growth in the ASEAN countries. Energy 34, 3573-3582. doi:10.1016/j.enpol.2005.07.011

Zheng, L., Song, J., Li, C., Gao, Y., Geng, P., Qu, B., Lin, L., 2014. Preferential policies promote municipal solid waste (MSW) to energy in China: Current status and prospects. Renew. Sustain. Energy Rev. 36, 135-148. doi:10.1016/j.rser.2014.04.049 